\title{
The Psychic Alternation Theory (PAT) - Model of Life Stage Crises in general and Mid-life Crisis in Particular
}

\author{
KV. Anoopkumar ${ }^{1 *}$, Annuradha Anoop ${ }^{2}$
}

\section{ABSTRACT}

Human mind in the psychoanalytic framework is understood to be structurally consisting of the triad of Id, ego and super ego. According to the psychic alternation outlook; the ego rather than being a mere mediating force, is understood to be a dynamic concept, subjected to inherent internal transformations, periodically. Hence there is a cyclic transformation of the 'ego' under the influence of its inherently predetermined and periodically fluctuating driving forces ('eros' \& 'thanatos'). The "Psychic Alternation Theory" postulates that, this inherent tendency towards ego transformations, contributes to the possible origin of life stage crises like Midlife-crisis. This transformation appears to be an unconscious tendency inherent to all individuals irrespective of racial, cultural or geographical differences. Moreover this transformation of the nature of the unconscious aspect of 'ego', from 'life-centered' to 'death-centered', seems to be persistent and periodically cyclic in any individual. In spite of this the appearance of a life-stage crisis at any vulnerable point in lifespan is not a universal phenomenon, owing to the influence of the 'egostrength' emanating from the cross sectional disposition of the 'will'.

Keywords: Lifespan, Crisis periods, Constructive periods, Will, libido, Ego-strength

Human mind in the psychoanalytic framework is understood to be structurally consisting of the triad of Id, ego and super ego. The ego is postulated to be mediating between, the raw uninhibited tendencies emanating from the id and the moral and idealistic restrictions (cultural/environmental) originating from the acquired wisdom of the super ego.

According to the proposed psychic alternation theory; the ego rather than being a mere mediating force, is understood to be a dynamic concept, subjected to inherent internal transformations, periodically. The basis of such transformations stem from the fact that the ego transcends all the three layers of consciousness (the conscious, preconscious and the unconscious) throughout its function of mediation. During such mediations, it is subjected to the influence of two main

\footnotetext{
${ }^{1}$ Assistant Professor of Psychology, Ambedkar University, Delhi, India

${ }^{2}$ Research Scholar, Indian Institute of Science (IISC), Bangalore, India

*Responding Author

(C) 2016 Anoopkumar KV, Annop A; licensee IJIP. This is an Open Access Research distributed under the terms of the Creative Commons Attribution License (http://creativecommons.org/licenses/by/2.0), which permits unrestricted use, distribution, and reproduction in any Medium, provided the original work is properly cited.
} 


\section{The Psychic Alternation Theory (PAT) - Model of Life Stage Crises in general and Mid-life Crisis in Particular}

forces; the 'will', originating from the conscious aspect of ego and the momentary 'libido' originating in the unconscious aspect of the ego.

The 'libido,' is, at a given point in time, understood to be further influenced (or periodically dominated) by one of its two driving and energizing factors; namely the 'eros' and the 'thanatos'. This domination of the unconscious aspect of 'ego' by either of the two factors ('eros' or 'thanatos') is postulated to be inherently periodic in nature.

The 'thanatos' dominates over the 'libido' in a manner that it coincides with certain discrete periods in the lifespan, more or less in a predetermined mode. These periods can be called the 'crisis periods'; meaning, periods during which the destructive forces from the unconscious are more influential. The remaining discrete periods of the lifespan are dominated by the constructive forces originating from the 'id', leading to a diametrically opposite disposition. The 'eros' dominates over the 'libido' during these times and it coincides with certain roughly demarcated periods in lifespan. These periods can be called the 'constructive periods'; meaning; periods during which the constructive forces from the unconscious are more influential.

Another important factor that determines the final outcome or ego-function is the 'Will'. The origin and nature of 'will' is attributed to two factors: the 'environment' and the 'individual differences'. The 'environment' implies the situational or the circumstantial milieu of the individual. The 'individual differences' imply the genetic factors (physique, health, inherited qualities etc.) The interaction between the 'environment' and the 'individual difference' will determine the strength and resilience of 'will', also known as the 'ego strength'. The 'ego strength' is the conscious aspect of the 'ego' which can be ordinarily inferred as an individual's self efficacy when faced with a stressful event.

At each stage of the human life span, the final direction of the 'ego- function' (negative or positive) is determined by the resultant outcome of the interaction between the underlying conscious aspect of the 'ego'; (ego strength) the 'Will' and the unconscious aspect of the 'ego' (psychic energy derived from 'eros' or 'thanatos') the 'Libido'.

The crisis periods, approximately correspond or coincide with the onset of 'adolescent transition phase', 'midlife' and 'middle old-age' in the continuum of the human life span. Conversely the constructive periods roughly coincide with phases of lifespan like; early childhood, young adulthood, early old age etc.

Hence there is a cyclic transformation of the 'ego' under the influence of its inherently predetermined and periodically fluctuating driving forces ('eros'\& 'thanatos'). Essentially this 


\section{The Psychic Alternation Theory (PAT) - Model of Life Stage Crises in general and Mid-life Crisis in Particular}

unconscious aspect of periodic 'ego-transformation,' is completely outside the sphere of the individual's conscious awareness. The basic nature of the unconscious aspect of 'ego,' follows a cyclic tendency of periodic transformations ranging from construction, to destruction and then back to construction and so on. Most importantly "The Psychic Alternation Theory" provides an explanation for the augmented possibility of three periods of lifespan namely 'adolescence', 'mid-life' and 'middle old-age', to be inherently vulnerable to crisis formation.

During the aforementioned crisis-stages, the unconscious aspect of the 'ego' is dominated by the destructive tendencies emanating from the naturally dominant 'thanatos'. But this in itself is not a sufficient condition for the triggering of a 'life crisis'. Final outcome of intra-psychic disposition (ego-function) depends on its (Libido) interaction with the conscious aspect of the 'ego'(Will). This shall determine whether a crisis would materialize or not. If the degree of resilience of the 'will' or the ego strength is low at a crisis period, the result is a life stage crisis. If the degree of resilience of the 'will' or ego-strength is high, the individual sails through the period with least discomfort.

According to the 'Psychic Alternation Theory', for example; the negative direction of egofunction at 'Mid-Life' leading to the midlife crisis, is conceptualized to be an outcome of, a transformed unconscious aspect of 'ego'(destructive and irrational by nature) interacting with its weak conscious aspect (poor ego-strength). That is, the unconscious aspect of 'ego' is mediating for the individual's compatibility with the external reality, under the increasing influence of a 'Libido' (psychic energy) majorly powered or driven by the 'Thanathos' (destructive forces). This is in stark contrast to the situation at an earlier stage (e.g. early/young adulthood), when the unconscious aspect of the 'ego' was mediating under the influence of the 'Libido' (psychic energy) majorly driven by the 'eros' (constructive forces).

This transformation appears to be an unconscious tendency inherent to all individuals irrespective of racial, cultural or geographical differences. Moreover this transformation of the nature of the unconscious aspect of 'ego' from 'life-centered' to 'death-centered' seems to be persistent and periodically cyclic in any individual. In spite of this the appearance of a life-stage crisis at any aforementioned vulnerable point in lifespan is not universal, owing to the influence of the ego-strength.

In a nutshell, the "Psychic Alternation Theory" proposed hereby, postulates about the inherent tendency towards ego transformations in individuals, in a periodic manner that follows a course of cyclic alternation, permeating life-span from birth to death; thereby contributing to the possible origin of life stage crises.

(C) The International Journal of Indian Psychology, ISSN 2348-5396 (e) | ISSN: 2349-3429 (p) | 170 
The Psychic Alternation Theory (PAT) - Model of Life Stage Crises in general and Mid-life Crisis in Particular

\section{PSYCHIC ALTERNATION THEORY OF LIFE STAGE CRISES} [PEAK FUNCTIONING "Eros"]

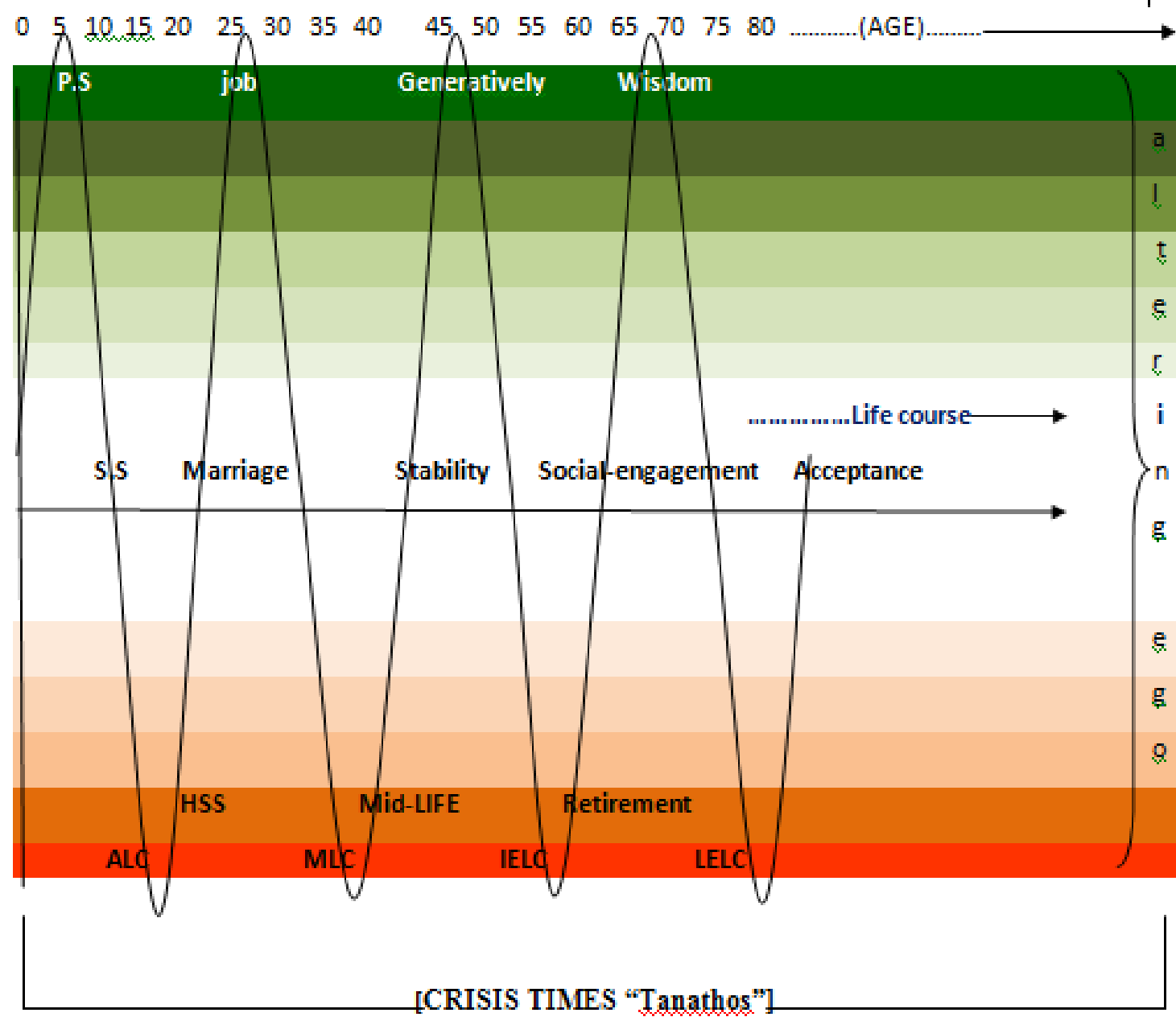

The Psychic Alternation theory of Developmental Life-Stage crises fig: 1.0

\section{Abbreviations:-}

ALC=Adolescent Life crisis

P.S=Primary Schooling

MLC=Midlife Crisis

H.S.S=Higher

Secondary Schooling

IELC=Initial Elderly Life Crisis

LELC=Later elderly life Crisis 


\section{The Psychic Alternation Theory (PAT) - Model of Life Stage Crises in general and Mid-life Crisis in Particular}

\section{PROPOSING A THEORETICAL CONSTRUCT FOR 'MID-LIFE CRISIS'}

To understand Mid-Life it in its full essence contrasting it with other stages of life is essential. Developmentally life stages can be classified in a simplified manner as; birth, infancy, childhood, adolescence, adulthood, old age and death. Having stated thus, it would be logical to remember that these are not natural stages and are mere classification of convenience for academic research and deliberations. In spite of the absence of any watertight age related criteria; there definitely exist a loose correlation between the mental process at various stages and the possible age range of the stages. To state for example; the adolescent identity crisis is definitely not going to occur to an individual in his late fifties. The theory that there exist no strict chronological age-related or growth related limitations to any stages hence doesn't mean there is no logical criteria at all; it just implies that the degree of freedom is broader.

In accordance with the stage wise classification, the stage of Mid-Life would further encompass the sub-stages of young adulthood, middle adulthood and late adulthood. As mentioned earlier, real life flows in a continuum like a stream, and not in stages. In that sense Mid-life can include many a times, the later part of early adulthood too, as more than the chronological age by itself, it is certain experiences that are the pre-requisite for a stage of adult life to be designated as 'Mid-Life'.

Mid-life is the period when usually for the first time in his/her life, the adult seriously contemplates on the concept of death as an imminent possibility. What is being referred to here is an emotional insight into the concept, rather than just an intellectual understanding. Many undergo the first-hand experience of the death of a loved parent. The thought of an impending death encroaches the boundary of conscious awareness like never before. Body signs of aging starts popping up, and unprotected and singular the person finds himself at the top of the generational ladder, acting out a social role with a limited degree of personal freedom of choice.

'What all you could be' of yesterday has narrowed down to 'what you are now' of today, and adjustment with this logical present becomes essential. Initial Signs of the inevitable process of decline in physical strength, cognitive agility and vitality, combined with the emotional understanding of limitations of 'the self' derived from experiences in life, forces a person sometimes into a meticulous comparative review of own life story hitherto. Compatibility if perceived, with an earlier harbored vision of the self as to 'how it should be', begets normalcy and adjustment. Perception of incompatibility triggers dissatisfaction and unrest, which propels the mental energy to find an alternative to restore normalcy and bring about adjustment. The peculiar experiences that contribute towards the formation of a crisis at this stage are thought to appear universally roughly between later part of early adulthood and late adulthood. 


\section{The Psychic Alternation Theory (PAT) - Model of Life Stage Crises in general and Mid-life Crisis in Particular}

Some people perceive life to be unsatisfactory at Mid-Life. This may be due to objective or subjective perception of circumstances as hindrances in development or as something that denote failure. Negative experiences/circumstances at Mid-life or the vice-versa i.e. the experiences which are interpreted as negative by people at mid-life; inculcate a fear of imminent death.

Death here seems to be symbolic in the form of loss of youthfulness, vitality and attractiveness. This also brings to the forefront the stark reality that, it is perhaps impossible to recapture that lost vigor. A painful realization sets in, that to relive those past times permeated by an earlier vitality, is practically impossible. This leads to a sense of timelessness in life and a need to compensate for the time lost. The pendulum of mindset swings back from a collective mind-set to that of an individualistic mind-set. The action pattern changes from that of a 'constructive and tolerance based - rational' concept to that of a 'destructive and need gratification basedirrational' concept, aimed at compensating for the perceived loss of time and energy. This involves a re-evaluation of the past in the light of the current subjective lack of life satisfaction, which paints all past efforts as misdirected and futile.

Efforts; mental, social and physical, that has gone into ensuring conformity and conscious suppression of unacceptable fantasies of the self, appear unproductive, resulting in a period of disillusionment and intra-psychic conflicts. This lowers the control of the ego on the Id. With that diminishes the perceived importance of ego and thus far preserved formidable impermeability of the ego ideals. Lack of insight coupled with the energy derived from the pent up negative emotion emerging from anticipated fear of death or doom, leads to the intensification of the raw uninhibited processes in the unconscious.

Instead of mediating between the super-ego and the Id, the ego, away from the conscious awareness, is set into motion to mediate predominantly for the Id. The primary catalyst is the perception of lack of time left in one's life. From this point on, the overt actions are in part determined by the unconscious, which operates with sole purpose of irrational pleasure-seeking fueled by the 'Thanatos'.

According to the 'Psychic Alternation Theory' the negative direction of ego-function at 'MidLife' leading to the midlife crisis, is conceptualized to be an outcome of, a transformed unconscious aspect of 'ego'(destructive and irrational by nature) interacting with its weak conscious aspect (poor ego-strength). That is, the unconscious aspect of 'ego' is mediating for the individual's compatibility with the external reality, under the increasing influence of a 'Libido' (psychic energy) majorly powered or driven by the 'Thanathos' (destructive forces). This is in stark contrast to the situation at an earlier stage (e.g. early/young adulthood), when the unconscious aspect of the 'ego' was mediating under the influence of the 'Libido' (psychic energy) majorly driven by the 'eros' (constructive forces). In the unfortunate event of such a 


\section{The Psychic Alternation Theory (PAT) - Model of Life Stage Crises in general and Mid-life Crisis in Particular}

libido state interacting with a poor 'Will' or lack of ego strength; a crisis is automatically triggered.

The above mentioned mental processes results in the outcome of the individual's action to be irrational, illogical and many a times self-defeating. It appears more so in contrast with previous life stage or sub-stage. This mental process is behaviorally displayed as a change which appears to be sudden, radical, and destructive and out of touch with the person's ordinary nature or from a recent well-adjusted past.

Midlife crisis is hence being proposed to be a particular stage-attached cross-section in the path of 'psychic alternation'. This stage is marked by the psychological transition from adulthood to old age. An individual at this stage is faced with the formidable challenge of accepting his death and committing to the rest of life in a constructive manner.

A crisis is shaped when this acceptance is not formed and an attempt is made to continue with the mentality typical of the pre-transition stage. This tendency to forcefully hold on to the mental-set typical of a previous stage brings about significant intra-psychic conflict in the individual. This overt part of the crisis may not be a universal phenomenon and varies from person to person and depends upon individual circumstances.

The triggering of the crisis is usually associated with the perception of lack of life-satisfaction at a conscious level. A plethora of factors like; social, interpersonal and intra-personal, may contribute to such a perception. When such a perception of lack of life-satisfaction occurs at midlife, it in turn leads to the weakening of the 'will' or 'ego-strength' which is the conscious aspect of the 'ego'. This is automatically met with the unconscious aspect of the 'ego' that is naturally predisposed to be under the influence of the 'Libido' (thanathos) emerging from the Id. This leads to the escalation of the perception of dissatisfaction into a full-fledged crisis, popularly termed as 'Mid-life Crisis'. 
The Psychic Alternation Theory (PAT) - Model of Life Stage Crises in general and Mid-life Crisis in Particular

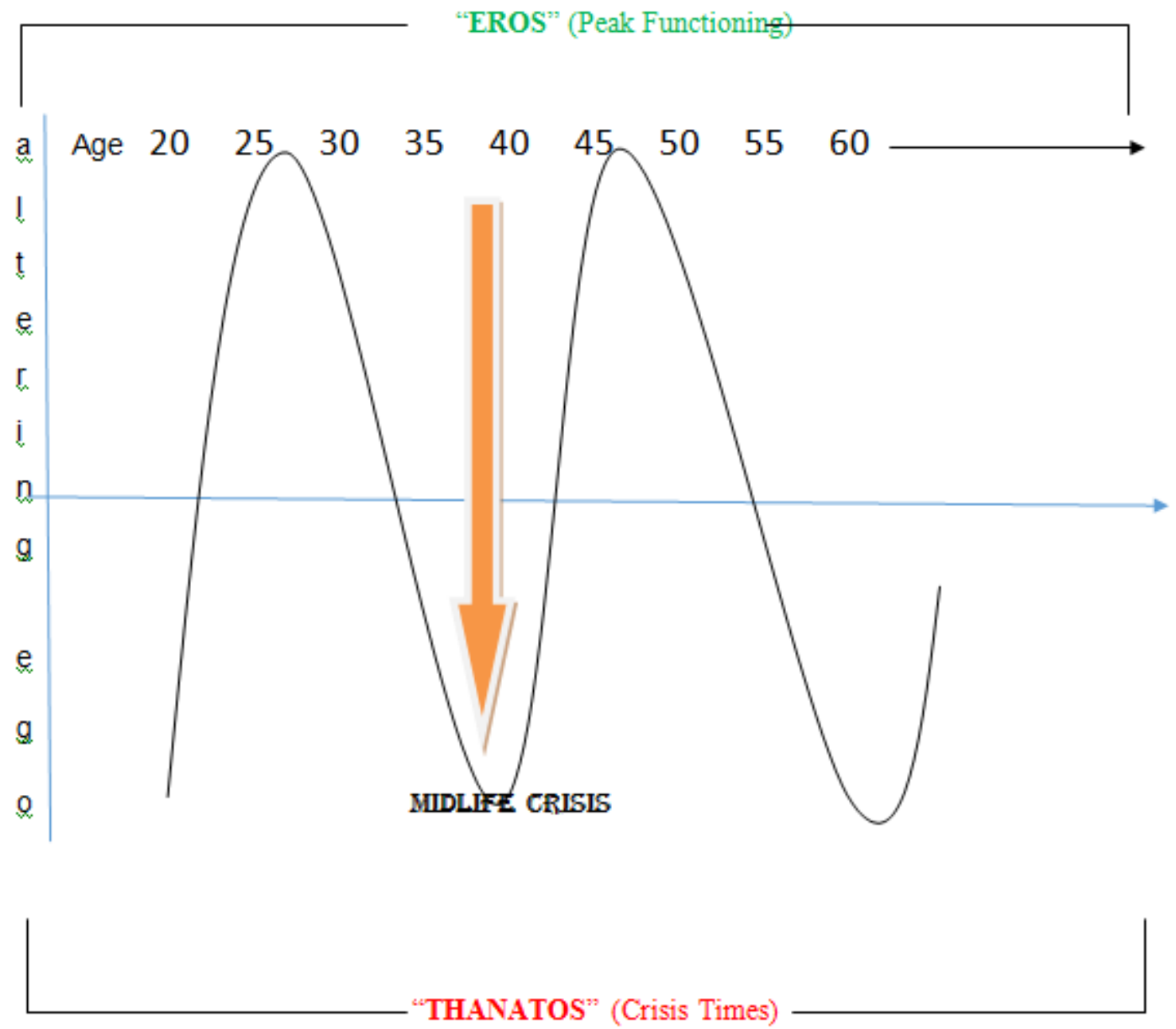

\section{The Psychic Alternation theory of Midlife crisis fig: 1.1}

With the onset of a midlife crisis there transpires a plodding perception of lack of joy (vitality and contentment) in usual mundane life activities which hitherto appeared purposeful and gratifying. This loss of pleasure leads to a meta-cognitive dilemma involving an evaluative self review. Discernment of an existential meaninglessness arouses a state of negative emotion and feeling in the individual. This subtle mood change brings about a gradual but sweeping change in the pattern of interpersonal relationship resulting in distortions and imbalances. The ability to derive fun and enjoyment from any activity, person or matter with in the usual circumstances, almost entirely wanes. Such a state of mental affair on progressive accumulation results in significant dissatisfaction in socio-emotional, professional and routine functioning of the individual. In its extreme it can culminate in development of neuroticism.

(c) The International Journal of Indian Psychology, ISSN 2348-5396 (e)| ISSN: 2349-3429 (p) | 175 


\section{The Psychic Alternation Theory (PAT) - Model of Life Stage Crises in general and Mid-life Crisis in Particular}

\section{BIBLIOGRAPHY}

Almeida, D. M., \& Horn, M. C. (2004). Is daily life more stressful during middle adulthood? In O. G. Brim \& C. D. Ryff\& R. C. Kessler (Eds.), how healthy are we? A national study of well-being at midlife (pp. 425-451). Chicago: University of Chicago Press.

Auerbach, S. M., \& Kilmann, P. R. (1977). Crisis intervention: A review of outcome research. Psychological Bulletin, 84(6), 1189.

Baird, B. M., Lucas, R. E., \& Donnellan, M. B. (2010). Life satisfaction across the lifespan: Findings from two nationally representative panel studies. Social indicators research, 99(2), 183-203.

Baltes, P. B., \& Baltes, M. M. (1990). Psychological perspectives on successful aging: The model of selective optimization with compensation.Successful aging: Perspectives from the behavioral sciences, 1, 1-34.

Baltes, P. B., \& Smith, J. (1990). Toward a psychology of wisdom and its ontogenesis. Wisdom: Its nature, origins, and development, 1, 87-120.

Bamberger, J. (1982). Growing up prodigies: The midlife crisis. New Directions for Child and Adolescent Development, 1982(17), 61-77.

Barbanel, L. (1990). Women therapists at midlife. Psychotherapy in Private Practice, 8(2), 79-86.

Barbarnel, L. (1989) The analyst's death: Issues in clinical practice (a symposium). Contemporary Psychoanalysis,25:413-448.

Baumeister, R. F. (1986). Identity: Cultural change and the struggle for self. New York: Oxford University Press.

Baumeister, R. F. (1991). Meanings of life. Guilford Press.

Beaumont, S. L., \& Zukanovic, R. (2005). Identity Development in Men and its Relation to Psychosocial Distress and Self-Worth. Canadian Journal of Behavioural Science/Revue canadienne des sciences du comportement,37(1), 70.

Bellah, R. N., Madsen, R., Sullivan, W. M., Swidler, A. and Tipton, S. M. (1985). Habits of the heart: Individualism and commitment in American life. Berkeley, CA: University of California Press.

Benjamin, D. J., Kimball, M. S., Heffetz, O., \& Rees-Jones, A. (2012). What do you think would make you happier? What do you think you would choose?. The American economic review, 102(5), 2083.

Bertrand, R. M., \& Lachman, M. E. (2003). Personality development in adulthood and old age. Handbook of psychology.

Black, K. (2011). Business statistics: for contemporary decision making. John Wiley \& Sons.

Blanchflower, D. G., \& Oswald, A. J. (1994). The wage curve. MIT press.

Blanchflower, D. G., \& Oswald, A. J. (2008). Is well-being U-shaped over the life cycle?. Social science \& medicine, 66(8), 1733-1749.

Blanchflower, D. G., \& Oswald, A. J. (2011). International happiness: A new view on the measure of performance. The Academy of Management Perspectives, 25(1), 6-22.

(c) The International Journal of Indian Psychology, ISSN 2348-5396 (e)| ISSN: 2349-3429 (p) | 176 


\section{The Psychic Alternation Theory (PAT) - Model of Life Stage Crises in general and Mid-life Crisis in Particular}

Booth, A. L., \& Van Ours, J. C. (2008). Job Satisfaction and Family Happiness: The Part-Time Work Puzzle*. The Economic Journal, 118(526), F77-F99.

Booth, A. L., \& Van Ours, J. C. (2009). Hours of work and gender identity: does part-time work make the family happier?. Economica, 76(301), 176-196.

Bourdieu, Pierre. (1977). Outline of a Theory of Practice. Cambridge University Press.

Boyce, C. J., \& Wood, A. M. (2011). Personality and the marginal utility of income: Personality interacts with increases in household income to determine life satisfaction. Journal of Economic Behavior \& Organization,78(1), 183-191.

Braverman, S., \& Paris, J. (1993). The male mid-life crisis in the grown-up resilient child. Psychotherapy: Theory, Research, Practice, Training, 30(4), 651.

Brim, O. G. (1976). Theories of the male mid-life crisis. The Counseling Psychologist.

Calvert, C. (2008). Tinker's Midlife Crisis: Tattered and Transgressed but Still Standing. Am. UL Rev., 58, 1167.

Carstensen, L. L., Turan, B., Scheibe, S., Ram, N., Ersner-Hershfield, H., Samanez-Larkin, G. R., ... \& Nesselroade, J. R. (2011). Emotional experience improves with age: evidence based on over 10 years of experience sampling. Psychology and aging, 26(1), 21.

Cavanaugh, J., \& Kail, R. (2007). Human Development. Thomson Learning Inc. California, USA.

Chassin, L., Presson, C. C., \& Sherman, S. J. (1987). Applications of social developmental psychology to health behaviors. Contemporary topics in developmental psychology, 353373.

Cheng, T. C., Powdthavee, N., \& Oswald, A. J. (2015). Longitudinal Evidence for a Midlife Nadir in Human Well-being: Results from Four Data Sets. The Economic Journal.

Chiriboga, D.A. (1997). Crisis, challenge, and stability in the middle years. In M.E. Lachman\& J.B. James (Eds.), Multiple paths of midlife development (pp. 293-343). Chicago: University of Chicago Press.

Chomsky, N. (2010). Hopes and prospects. Haymarket Books.

Ciernia, J. R. (1983). An examination of the businessman's mid-life crisis.

Ciernia, J. R. (1985). Death concern and businessmen's mid-life crisis.Psychological reports, 56(1), 83-87.

Clark, A. E., \& Oswald, A. J. (1994). Unhappiness and unemployment. The Economic Journal, 648-659.

Clark, A., Oswald, A., \& Warr, P. (1996). Is job satisfaction U-shaped in age?. Journal of occupational and organizational psychology, 69(1), 57-81.

Coleman, L. M., \& Antonucci, T. C. (1983). Impact of work on women at midlife. Developmental Psychology, 19(2), 290.

Conway, J. (1997). Men in midlife crisis. David C Cook.

Diener, E., Inglehart, R., \& Tay, L. (2013). Theory and validity of life satisfaction scales. Social Indicators Research, 112(3), 497-527. 


\section{The Psychic Alternation Theory (PAT) - Model of Life Stage Crises in general and Mid-life Crisis in Particular}

Easterlin, R. A. (2003). Building a better theory of well-being.

Easterlin, R. A. (2003). Explaining happiness. Proceedings of the National Academy of Sciences, 100(19), 11176-11183.

Erickson, C. E. (1950). The counseling interview. New York: Prentice-Hall.

Erikson, E. H. (1959). Identity and the life cycle: Selected papers.Psychological issues.

Erikson, E.H. (1963). Childhood and society (2nd ed.). New York: Norton.

Everly, G. S., \& Mitchell, J. T. (1999). Critical incident stress management-CISM-: A new era and standard of care in crisis intervention. Chevron Pub..

Fossati, P., Hevenor, S. J., Graham, S. J., Grady, C., Keightley, M. L., Craik, F., \& Mayberg, H. (2014). In search of the emotional self: an fMRI study using positive and negative emotional words. American Journal of Psychiatry.

Freund, A. M., \& Ritter, J. O. (2009). Midlife crisis: A debate. Gerontology,55(5), 582-591.

Frey, B. S., \& Stutzer, A. (2002). The economics of happiness. World Economics, 3(1), 1-17.

Giddens, A. (1991). Modernity and self-identity: Self and society in the late modern age. Stanford, CA: Stanford University Press.

Gidron, Y., Russ, K., Tissarchondou, H., \& Warner, J. (2006). The relation between psychological factors and DNA-damage: a critical review. Biological psychology, 72(3), 291-304.

Gilligan, C. (1982). In a different voice. Cambridge, MA: Harvard University Press.

Gilligan, C. (1995). Hearing the difference: theorizing connection. Hypatia, 10(2), 120-127.

Gould, R. L. (1978). Transformations: Growth and change in adult life. Simon \& Schuster.

Guttmann, J. (1987). Test anxiety and performance of adolescent children of divorced parents. Educational Psychology, 7(3), 225-229.

Hagestad, G. O., \& Neugarten, B. L. (1985). Age and the life course.Handbook of aging and the social sciences, 2, 35-61.

Hank, K. (2007). Proximity and contacts between older parents and their children: A European comparison. Journal of Marriage and Family, 69(1), 157-173.

Harris, R. L., Ellicott, A. M., \& Holmes, D. S. (1986). The timing of psychosocial transitions and changes in women's lives: An examination of women aged 45 to 60 . Journal of personality and social psychology, 51(2), 409.

Hayes, S. C., Strosahl, K. D., \& Wilson, K. G. (1999). Acceptance and commitment therapy: An experiential approach to behavior change. Guilford Press.

Hayes, S.C, Strosahl, K.D., \& Wilson, K.G. (2012). Acceptance and commitment therapy: The process and practice of mindful change (2nd edition). New York, NY: The Guilford Press.

Hedlund, B., \& Ebersole, P. (1983). A test of Levinson's mid-life re-evaluation. The Journal of genetic psychology, 143(2), 189-192.

Helminiak, D. A. (1994). Men and women in midlife transition and the crisis of meaning and purpose in life, a matter of spirituality.

(C) The International Journal of Indian Psychology, ISSN 2348-5396 (e)| ISSN: 2349-3429 (p) | 178 


\section{The Psychic Alternation Theory (PAT) - Model of Life Stage Crises in general and Mid-life Crisis in Particular}

Hermans, H. J., \& Oles, P. K. (1999). Midlife crisis in men: Affective organization of personal meanings. Human Relations, 52(11), 1403-1426.

Hoffman, E., Relwani-Garg, N., Kaneshiro, S., \& Kapur, S. (2012). Peak-experiences among Indians in midlife. Indian Journal of Positive Psychology,3(3), 217.

Hooker, K., \& McAdams, D. P. (2003). Personality reconsidered: A new agenda for aging research. The Journals of Gerontology Series B: Psychological Sciences and Social Sciences, 58(6), P296-P304.

Hopcke, R. H. (1992). Midlife, gay men, and the AIDS epidemic. Quadrant: Journal of the CG Jung Foundation for Analytical Psychology.

Howard A, Bray DW, (1988), Managerial lives in transition: Advancing age and changing times. New York: Guilford.

Howard, A., \& Bray, D. W. (1988). Managerial lives in transition: Advancing age and changing times. Guilford Press.

Inkeles, A., \& Levinson, D. J. (1969). National character: The study of modal personality and sociocultural systems. The handbook of social psychology, 4, 418-506.

Jaques, E. (1965). Death and the mid-life crisis. The International journal of psycho-analysis, 46(4), 502.

Jaques, E. (1970). Work, creativity, and social justice.

Jaques, E. (1980). The midlife crisis. The course of life: Psychoanalytic contributions toward understanding personality development, 3, 1-23.

Jung, C. G. (1923). Psychological types: or the psychology of individuation.

Jung, C. G. (1933). Modern Man in Search of a Soul. London: Kegan Paul Trench Trubner, (1955 ed. Harvest Books ISBN 0-15-661206-2)

Jung, C. G. (1971). The stages of life. The portable Jung, 3-22.

Kearl, M. C., \& Hoag, L. J. (1984). The social construction of the midlife crisis: A case study in the temporalities of identity. Sociological Inquiry,54(3), 279-300.

Keegan, L. (1994). The nurse as healer. Delmar Pub.

Kegan, R. (1998). In over our heads: The mental demands of modern life. Harvard University Press.

Kelly, B., \& Perkins, D. F. (Eds.). (2012). Handbook of implementation science for psychology in education. Cambridge University Press.

Kelly, E. L. (1955). Consistency of the adult personality. American Psychologist, 10(11), 659.

Klohnen, E. C., Vandewater, E. A., \& Young, A. (1996). Negotiating the middle years: Egoresiliency and successful midlife adjustment in women.Psychology and Aging, 11(3), 431.

Kruger, A. (1994). The midlife transition: Crisis or chimera?. Psychological reports, 75(3), 12991305.

Lachman, M. E. (2004). Development in midlife. Annu. Rev. Psychol., 55, 305-331. 


\section{The Psychic Alternation Theory (PAT) - Model of Life Stage Crises in general and Mid-life Crisis in Particular}

Lachman, M. E., Lewkowicz, C., Marcus, A., \& Peng, Y. (1994). Images of midlife development among young, middle-aged, and older adults. Journal of Adult Development, 1(4), 201211.

Lang, I. A., Llewellyn, D. J., Hubbard, R. E., Langa, K. M., \& Melzer, D. (2011). Income and the midlife peak in common mental disorder prevalence.Psychological medicine, 41(07), 1365-1372.

Lawrence, B. S. (1980). The myth of the midlife crisis. Sloan Management Review, 21(4), 3549.

Le Bon, O., \& Le Bon, S. D. (2014). Age distribution curve in psychiatric admissions inversely correlates with Life Satisfaction. Psychiatry research,219(1), 232-234.

Levinson, D. J. (1978). The seasons of a man's life. Random House LLC.

Levinson, D. J. (1980). Toward a conception of the adult life course. Themes of work and love in adulthood, 265-290.

Levinson, D. J. (1986). A conception of adult development. American psychologist, 41(1), 3.

Lieberman, M., \& Peskin, H. (1992). Adult life crises. Handbook of mental health and aging, 120-143.

Mansfield, P. K., Koch, P. B., \& Voda, A. M. (1998). Qualities midlife women desire in their sexual relationships and their changing sexual response.Psychology of Women Quarterly, 22(2), 285-303.

Maslow, A. H. (1943). A theory of human motivation. Psychological review,50(4), 370.

McAdams, D. P. (2001). The psychology of life stories. Review of general psychology, 5(2), 100.

McAdams, D. P., Reynolds, J., Lewis, M., Patten, A. H., \& Bowman, P. J. (2001). When bad things turn good and good things turn bad: Sequences of redemption and contamination in life narrative and their relation to psychosocial adaptation in midlife adults and in students. Personality and Social Psychology Bulletin, 27(4), 474-485.

McDowell, I. (2010). Measures of self-perceived well-being. Journal of psychosomatic research, 69(1), 69-79.

Menon, U. (2001). Middle adulthood in cultural perspectives: The imagined and the experienced in three cultures. In M. E. Lachman (Ed.), Handbook of midlife development (pp. 40-74). New York: Wiley.

Michael C., and Lisbeth J. Hoag. (1984). The social construction of the midlife crisis: A case study in the temporalities of identity. Sociological Inquiry 54.3: 279-300.

Midlife crisis. (n.d.). Dictionary.com Unabridged. Retrieved February 22, 2016 from Dictionary.com website

Moen, P., \& Wethington, E. (1999). Midlife development in a life course context. Life in the middle: Psychological and social development in middle age, 3-23.

Morris, B. (1995). Executive women confront midlife crisis. Fortune, 132(6), 60-72.

Morris, B. (1995). Executive women confront midlife crisis. Fortune, 132(6), 60-72.

(c) The International Journal of Indian Psychology, ISSN 2348-5396 (e)| ISSN: 2349-3429 (p) | 180 


\section{The Psychic Alternation Theory (PAT) - Model of Life Stage Crises in general and Mid-life Crisis in Particular}

Neugarten, B. L. (1968). Middle age and aging: A reader in social psychology. University of Chicago Press.

Oishi, S., \& Graham, J. (2010). Social ecology lost and found in psychological science. Perspectives on Psychological Science, 5(4), 356-377.

Oles, P. K. (1999). Towards a psychological model of midlife crisis.Psychological reports, 84(3c), 1059-1069.

Oswald, A. J., \& Wu, S. (2010). Objective confirmation of subjective measures of human wellbeing: Evidence from the USA. Science, 327(5965), 576-579.

Oswald, Andrew J., and Stephen Wu. "Well-being across America." Review of Economics and Statistics 93.4 (2011): 1118-1134.

Palk, L. C. (2015). An exploration study of midlife transition in South Africa: in search of the midlife crisis (Doctoral dissertation).

Peterson, B. E., \& Klohnen, E. C. (1995). Realization of generativity in two samples of women at midlife. Psychology and Aging, 10(1), 20.

Raphael, B. (1986). When disaster strikes: How individuals and communities cope with catastrophe. Basic Books (AZ).

Roberts, P., \& Newton, P. M. (1987). Levinsonian studies of women's adult development. Psychology and Aging, 2(2), 154.

Robinson, O. (2007). Pre-midlife crisis and the limits of an extrinsic orientation.

Rosenberg, S. D., \& Farrell, M. P. (1976). Identity and crisis in middle aged men. The International Journal of Aging and Human Development, 7(2), 153-170.

Ryff, C. D., Lee, Y. H., Essex, M. J., \& Schmutte, P. S. (1994). My children and me: midlife evaluations of grown children and of self. Psychology and aging, 9(2), 195.

Sandoval, J. (1985). Crisis counseling: Conceptualizations and general principles. School Psychology Review.

Scarf, M. (1980). Unfinished business: Pressure points in the lives of women. New York: Doubleday.

Schwartz, S. H. (1971). Modes of representation and problem solving: Well evolved is half solved. Journal of Experimental Psychology, 91(2), 347.

Sharp, D. (1988). The survival papers: Anatomy of a midlife crisis (Vol. 35). Inner City Books.

Sheehy, G. (1976). Passages. New York: EP Dutton \& Co.

Shek, D. T. (1996). Midlife crisis in Chinese men and women. The Journal of psychology, 130(1), 109-119.

Smith, K. W., Avis, N. E., \& Assmann, S. F. (1999). Distinguishing between quality of life and health status in quality of life research: a meta-analysis.Quality of Life Research, 8(5), 447-459.

Stone, A. A., Schwartz, J. E., Broderick, J. E., \& Deaton, A. (2010). A snapshot of the age distribution of psychological well-being in the United States. Proceedings of the National Academy of Sciences, 107(22), 9985-9990. 


\section{The Psychic Alternation Theory (PAT) - Model of Life Stage Crises in general and Mid-life Crisis in Particular}

Swidler, A. (1986). Culture in action: Symbols and strategies. American sociological review, 273-286.

Warr, P. (1992). Age and occupational well-being. Psychology and aging,7(1), 37.

Waskel, S. A. (1995). Temperament types: Midlife death concerns, demographics, and intensity of crisis. The Journal of psychology, 129(2), 221-233.

Waskel, S. A. (1995). Temperament types: Midlife death concerns, demographics, and intensity of crisis. The Journal of psychology, 129(2), 221-233.

Wethington, E. (2000). Expecting stress: Americans and the "midlife crisis".Motivation and Emotion, 24(2), 85-103.

Wethington, E., Cooper, H., \& Holmes, C. S. (1997). Turning points in midlife. In I. H. Gotlib\& B. Wheaton (Eds.), Stress and adversity across the life course: Trajectories and turning points (pp. 215-231). New York: Cambridge University Press.

Wethington, E., Kessler, R. C., \& Brim, O. G. (2005). Midlife Development in the United States (MIDUS): Psychological Experiences Follow-Up Study, 1998. ICPSR02911-v1. Ann Arbor, MI: Inter-university Consortium for Political and Social Research.

Wethington, E., Kessler, R. C., \& Pixley, J. E. (2005). Turning points in adulthood. na.

Wethington.E, Pillemer.K.A\&Moen.P (1998) Social Integration in the Second Half of Life, Baltimore: Johns Hopkins University Press

Willig, C. (2001). Qualitative research in psychology: A practical guide to theory and method. Buckingham: OUP.

Willis, S. L., \& Reid, J. B. (Eds.). (1998). Life in the middle: Psychological and social development in middle age. Academic Press.

Wollman, D. (1993). Critical incident stress debriefing and crisis groups: A review of the literature. Group, 17(2), 70-83.

Wyatt, G. K., \& Friedman, L. L. (1998, May). Physical and psychosocial outcomes of midlife and older women following surgery and adjuvant therapy for breast cancer. In Oncology nursing forum (Vol. 25, No. 4, pp. 761-768).

Yeh, H. C., Lorenz, F. O., Wickrama, K. A. S., Conger, R. D., \& Elder Jr, G. H. (2006). Relationships among sexual satisfaction, marital quality, and marital instability at midlife. Journal of family psychology, 20(2), 339.

How to cite this article: Anoopkumar KV, Annop A (2016), The Psychic Alternation Theory (PAT)-Model of Life Stage Crises in general and Mid-life Crisis in Particular, International Journal of Indian Psychology, Volume 4, Issue 1, No. 82, ISSN:2348-5396 (e), ISSN:2349-3429 (p), DIP:18.01.157/20160401, ISBN:978-1-365-59365-9 